\title{
GANTI KERUGIAN PEMBEBASAN TANAH MILIK UNTUK KEPENTINGAN UMUM
}

\author{
Basyirah Mustarin \\ Universitas Islam Negeri Alauddin Makassar
}

\begin{abstract}
Road construction projects for public use, usually involve many locations of land owned by communities with ownership rights. The construction of public facilities made by the government prior to construction must carry out the stages of land acquisition as contained in Law No. 2 of 2012 concerning land acquisition for development in the public interest. The research method used is normative research by using the statutory approach and concept analysis approach. The results showed that the city government provided compensation for the location of land that would be affected by the construction of public facilities. The mechanism of land acquisition or land acquisition in the city is carried out by providing compensation to the value of the land price that will be released in an appropriate and fair manner based on article 9 paragraph (2) of Law Number 2 of 2012. Land issues so far are very relevant to be studied together and considered in depth in relation to policies in the field of land because at the level of policy implementation that has been shown so far has neglected the structural aspects of land tenure, which in turn caused various disputes.
\end{abstract}

Keywords: Compensation, Land Acquisition, Property Rights, Public Interest.

\begin{abstract}
Abstrak
Proyek pembuatan jalan untuk kepentingan umum, biasanya melibatkan banyak lokasi tanah yang dimiliki oleh masyarakat yang berstatus hak milik. Pembuatan sarana umum yang dibuat oleh pemerintah tersebut sebelum dibangun harus melakukan tahapan pembebasan lahan sebagaimana yang termuat dalam Undang-Undang Nomor 2 tahun 2012 tentang pengadaan tanah bagi pembangunan untuk kepentingan umum. Metode penelitian yang digunakan adalah penelitian normatif dengan melakukan pendekatan peraturan perundangundangan (Statute Approach) dan pendekatan analisis konsep (Conceptual Approach). Hasil penelitian menunjukkan bahwa pemerintah kota memberikan ganti kerugian atas lokasi tanah yang akan terkena pembuatan sarana umum tersebut. Mekanisme pembebasan tanah atau pengadaan tanah di kota dilakukan dengan memberikan ganti kerugian terhadap nilai harga tanah yang akan dibebaskan secara sesuai dan adil berdasarkan pasal 9 ayat (2) Undang-Undang Nomor 2 Tahun 2012. Persoalan tanah selama ini sangat relevan dan dipertimbangkan secara mendalam dalam kaitannya dengan kebijakan dibidang pertanahan karena ditingkat implementasi kebijakan yang diperlihatkan selama ini
\end{abstract}


telah mengabaikan aspek struktural penguasaan tanah yang pada akhirnya menimbulkan berbagai macam sengketa.

Kata Kunci : Ganti Kerugian, Hak Milik, Kepentingan Umum, Pembebasan Tanah.

\section{PENDAHULUAN}

Secara teoritis berdasarkan ketentuan dalam hukum kebendaan suatu hak atas kebendaan dikatakan "beralih" yaitu suatu proses berpindahnya hak atas tanah dari pemegang hak yang lama kepada pihak lain karena pemegang haknya "meninggal dunia". Proses pewarisan seperti ini disebut dengan pewarisan. Peralihan hak atas tanah tersebut terjadi karena hukum, artinya dengan meninggalnya seseorang pemegang hak atas tanah, maka otomatis hak atas tanah tersebut beralih kepada ahli warisnya. Jadi, ahli waris disini memperoleh peralihan hak atas karena suatu peristiwa hukum tertentu, bukan karena perbuatan hukum yang dilakukan oleh pemegang hak atas tanah selaku subjek hukum.

Suatu hak atas tanah dialihkan atau diperalihkan apabila hak atas tanah tersebut dipindahkan atau dipindahtangankan dari pemegang hak selaku subjek hukum kepada puhak lain karena perbuatan hukum yang sengaja dilakukan dengan tujuan agar pihak lain tersebut memperoleh hak atas tanah yanh dialihkan. Perbuatan hukum yang bertujuan mengalihkan hak atas tanah dapat berupa jual beli, tukar menukar, hibah, penyertaan dalam modal perusahaan (inberg), pemberian dengan wasiat dan lelang. Dalam proses peralihan atau pemindahan hak, pihak yang mengalihkan atau memindahkan hak harus mempunyai hak dan kewenangan untuk memindahkan hak, sedangkan bagi pihak yang memperoleh hak harus memenuhi syarat sebagai pemegang hak atas tanah yang baru.

Didalam terminologi hukum kata-kata Right diartikan hak legal, atau dasar untuk melakukan sesuatu tindakan secara hukum. Secara Yuridis, peralihan hak atas tanah dapat dilakukan melalui beberapa proses, antara lain:

1) Jual beli

2) Hibah

3) Tukar menukar

4) Pemisahan dan pembagian biasa

5) Pemisahan dan pembagian harta warisan

6) Penyerahan hibah wasiat

7) Hipotik

8) Credit verband

Terkait dengan pemindahan atau peralihan hak atas tanah, dilihat dari karakteristik hak dan proses peralihan haknya, memiliki unsur hukum berbeda, terutama yang terkait dengan syarat formil dan materil, prosedur, maupun 
mekanisme yang sangat ditentukan sifat atau keadaan subjek dan objek hak. Namun demikian syarat utama adalah harus adanya alat bukti hak atas tanah, yakni bukti kepemilikan secara tertulis (formil) yang berupa "sertifikat" (untuk tanah yang telah didaftarkan atau belum bersertifikat). Bukti yang dimaksud dapat berupa : akta jual beli, hibah, fatwa waris, surat kepurusan pemberian hak atas tanah dan bangunan, dan lain-lain. Hal tersebut untuk memberikan kepastian dan kekuatan hukum atas kepemilikan tanah, sehingga peralihan hak atas tanah tersebut memenuhi syarat legalitas menurut peraturan perundang-undangan yang berlaku.

Peralihan hak atas tanah menurut yuridis dilakukan secara tertulis dengan akta yang dibuat oleh pejabat yang berwenang dan didaftarkan pada Badan Pertanahan Nasional (kantor Pertanahan Kabupataen/kota). Langkah tersebut kait eraat dengan prosedur peralihaan hak atas tanah, karena prosedur menentukan legalitas dari peralihan hak atas tanah. Dengan demikian legalitas peralihan hak atas tanah sangat ditentukan oleh syarat formil maupun syarat materil, kewenangan mengaihkan maupun kewenangan pejabat untuk bertindak. Prosedur hukum beralihnya suatu hak atas tanah dapat ditelusuri baik sebelum maupun setelah berlakunya undang-undang pokok agraria (UUPA).

\section{METODE PENELITIAN}

Penelitian ini dilakukan berdasarkan studi pustaka dengan berbagai referensi jurnal dan buku serta beberapa artikel terbaik dan terupdate. Penelitian Pustaka (library research) yaitu Penelitian dilaksanakan dengan mengumpulkan data dan landasan teoritis dengan mempelajari buku, karya ilmiah, hasil penelitian terdahulu, jurnal-jurnal terkait, artikel-artikel yang terkait serta sumber-sumber yang terkait dengan penelitian sesuai dengan penelitian yang diteliti. Setelah semua data telah diperoleh berhasil dikumpulkan selama proses penelitian baik data primer dan data sekunder dianalisis secara kualitatif kemudian disajikan secara deskriptif yaitu menjelaskan, menguraikan, menggambarakan permasalahan yang berkaitan dengan ganti kerugian pembebasan tanah milik untuk kepentingan umum.

\section{PEMBAHASAN}

\section{A. Pembebasan Hak Atas Tanah Yang Belum Bersertifikat}

Untuk desa-desa dalam wilayah yang terpencil, kepala Badan Pertanahan Nasional dapat menunjuk PPAT sementara. Ketentuan ini dimaksudkan untuk memberikan pelayanan pada rakyat terpencil yang tidak ada PPAT untuk melaksanakan perbuatan hukum peralihan hak atas tanah. Mereka yang ditunjuk 
sebagai PPAT sementara adalah Pejabat Pemerintah yang menguasai keadaan daerah yang bersagkutan, yaitu Kepada Desa. ${ }^{1}$ Penunjukan Kepada Desa sebagai PPAT Sementara dilakukan oleh Kepala Badan Pertanahan Nasional berdasarkan letak desa yang sangat terpencil dan banyaknya bidang tanah yang sudah terdaftar di wilayah desa tersebut.

Keunikan dari PPAT Sementara dan PPAT Khusus adalah pada jabatan induksi instansi pemerintah yang dipegangnya, yang jika pejabat yang bersangkutan dimutasikan atau digantikan oleh orang lain sehingga tidak menjabat lagi. Maka otomatis tidak berwenang membuat akta PPAT sejak tanggal keputusan pemindahan atau penggantian pejabat yang bersangkutan. ${ }^{2}$ Akta jual beli merupakan suatu hal yang sangat penting yang berfungsi untuk terjadinya pemindahan hak milik atas tanah dan terjadinya kepemilikan tanah. Agar transaksi jual beli bisa dipertanggung jawabkanpihak penjual dan pembeli ingkar dan menjadi sengketa, maka keduanya saksi inilah yang akan menjelaskan kepada hakim bahwa mereka benar-benar telah melakukan jual beli. Kehadiran dua orang saksi yang dituliskan dalam sebuah akta jual beli diwajibkan untuk meminimalisir pengingkaran sebuah objek tanah yang pernah dipidahtangankan khususnya dengan jalur jual beli.

Jual beli harus dengan akta PPAT berdasarkan PP Nomor 24 Tahun 1997, PP Nomor 37 Tahun 1998 dan Peraturan Menteri Negara Agraria/Kepala Badan Pertanahan Nasional No.4 Tahun 1999, juga menimbulkan persoalan. Khususnya daerah pedesaan yang camat atau kepala desanya belum ditunjuk sebagai PPAT Sementara, sedangkan banyak penduduk pedesaan yang melakukan peralihan atas tanah khususnya dengaan jual beli tanah tanpa Akta PPAT, tetapi dilakukan dihadapan kepala desa atau Camat. Untuk jual beli tanah dengan status "hak milik adat" (belum berbentuk sertfikat) mengharuskan adanya keterangan tertulis dari lurah tentang kebenaran tanah yang diperjualbelikan di wilayah itu. Pemilik Girik atau ketitir yang dikeluarkan sebelum tahun 1960 bisa mendapatkan sertifikat dengan cara konversi. Adapun Girik atau ketitir yang dikeluarkan setelah tahun 1960 harus melalui permohonan hak kepada sub Direktorat Agraria Wilayah Kota. Kemudian bagi masyarakat yang membeli tanah untuk sebagian dari keseluruhan luas tanah yang tercantum pada Girik/Ketitir Hak milik adat diharuskan untuk meminta balik nama di Kantor IPEDA setelah mendapatkan akta PPAT/PPAT Sementara sebelum mengajukan permohonan untuk mendapatkan sertifikat.

\footnotetext{
${ }^{1}$ Penjelasan Pasal 7 ayat (2) Peraturan Pemerintah Nomor 24 Tahun 1997.

2 Pasal 6 ayat (4) dan pasal 9 ayat (4) peraturan Menteri Negara Agraria/ Kepala BPN Nomor 4 Tahun 1999.

90
} 
Untuk mendukung perbuatan hukum pendaftaran tanah, keabsahan akta jual beli tanah tergantung pada ketaatan PPAT menjalankan kewenangan jabatannya, yaitu:

1. Sertifikat yang menjadi objek perjanjian jual beli tanah tidak sedang dijadikan agunan bank, sengketa, atau dalam sitaan.

2. Sertifikat tanah yang menjadi objek perjanjian jual beli masih dalam proses permohonan hak di kantor pertanahan kabupaten /Kota.

3. Sertifikat tanah atas nama orang lain

4. Pembeli belum cukup umur

5. Calon pembeli ingin membeli tanah (khusus untuk wilayah sawah) tidak berdomisili di wilayah tempat tanah itu berada

6. Para pihak atau salah satunya belum cukup umur

7. Hak atas tanah berada dalam keadaan sengketa

8. Hak atas tanah dalam sistem peradilan negeri (conservatoir Beslag) atau sudah diserahkan kepada panitia urusan piutang

9. Bukan badan hukum yang berdasarkan PP. No.38 Tahun 1963 diperkenankan memiliki tanah dengan hak milik

10. Bidang tanah terletak diluar wilayah kerja PPAT

11. Calon pembeli tanah adalah orang asing

12. Tanah wakaf dan tanah yang sedang digadaikan

Selain itu dalam membuat akta jual beli, PPAT harus memperhatikan beberapa hal, yang juga merupakan kewenanganya yaitu:

1. Kedudukan atau status Penjual adalah pihak yang berhak menjual tanah Bila dalam hak milik atas tanh terdapat lebih dari 1 pemilik, maka yang berhak menjual adalah meraka yang memiliki tanah itu bersama - sama, dan dilarang dijual oleh satu orang saja. Pemilikan bersama hak milik atas tanah itu biasanya terjadi karena pewarisan atau dahulu pernah memmbeli secara patungan/bersama - sama, atau juga karena pernah diperoleh secara bersam - sama secara hibah. Jual beli tanah yang dilakukan hanya oleh 1 orang berakibat batal demi hukum, artinya sejak semula hukum menganggap tidak pernah terjadi jual beli. Dalam hal yang demikian, jelas kepentingan pembeli sangat dirugikan. Sebab ia sudah membayta harga tanah itu kepada penjual, sedangkan haknya atas tanah yang dibelinya tidak pernah veralih kepadanya. Walaupun mungkin si pembeli telah menguasai tanah itu, sewaktu -waktu orang yang berhak atas tanah itu dapat menunutut melalui pengadilan supaya tanah itu diserahkan kepadanya. Tuntutan itu sangat berlalasan sehingga pembeli tanah akan di paksa mengosongkan tanah. 
2. Penjual adalah pihak yang berwenang menjual, Untuk dapat bertindak sebagai penjual haus dipenuhi syarat tertentu, Untuk dapat bertindak sebagai penjual harus dipenuhi syarat tertentu, yakni usia harus dewasa menurut undang - undang, artinya cakap untuk malakukan perbuatan hukum jual beli tanah, misalnya:

a. Anak berumur 12 tahun tidak berwenang melakukan jual beli, walaupun ia yang berhak atas tanah itu. Jual beli terlaksana kalau yang bertindak adalah ayah dari anak itu sebagai oarang yang melakukan kekuasaan orang tua.

b. Sebidang tanah dalam sertifikat atas nama istrinya, sedangkan tanah itu adalah harta bersama dengan suaminya, maka istri tidak berwenang menjual sendiri tanah, malainkan bersama - sama suaminya, atau suaminya memberi persetujuan tertulis kepada istri. Demikian juga, bila istri yang harus memberi persetujuan kepada suami kalau suatu tnah sebagai harta bersama tertulis atas nama suami.

c. Kalau tanah tercatat atas nama, misalnya X, tetapi ia tunduk pada KUH perdata dan sedang berada di bawah pengampunan, maka yang berwenang menjual tanah itu adalah Pengampu si $\mathrm{X}$, tetapi harus ada izin dari Ketua Pengadilan Negeri.

3. Pembeli adalah pihak yang diperkenankan membeli tanah

Untuk dapat membeli danga status hak milik, maka tidak semua pembeli dapat tanah dengan status hak milik, seperti perusahaan terbatas, perseroan komanditer tidak boleh membeli/memilikinya, juga WNA.

Pembatasan wewenang lainya adalah akta jual beli tanah tidak boleh dilakukan oleh PPAT yang bukan wilayah kerjanya. Ketidakhati - hatian pembelian tanah tanpa melalui PPAT akan menimbulkan kerugian mengenai luas tanah yang dibelinya. Sering kali jual beli tanah dilakukan dengan saksi dan surat jual beli dibuat oleh kapala Desa. Luas yang digunkan berupa angka yang mungkin sekali berasal dari petuk atau surat keterangan lain yang tidak didasari pengukuran dan perhitungan kadastal. Karena itu, pada waktu akan disertifikatkan, perlu tanah itu diukur, dihitung dan digambar, lalu dihitung luas tanahanya. Kesepakatan letak batas itu yang diukur oleh Badan Pertanahan Nasional dan dibuktikan dengan tanda tangan pembeli dan pemilik tanah yang berbatasan.

Dalam transaksi jual beli, tidak sedikit kasus yang muncul, misalnya dalam pemindahan hak atas tanah tersebut terdapat pemalsuan tanda tangan istri dari pihak penjual, seakan -akan pihak istri memberikan persetujuan. Tuntutan akan datang dari istri untuk meminta pembatalan atas pemindahan 
hak atas tanah tersebut yang telah dibalik nama ke atas nama pembeli. Perbuatan hukum jual beli tanah mengakibatkan perubahan data yuridis pendaftaran tanah.

Dalam peraturan Kepala Badan Pertanahan Nasional Nomor 6 Tahun 1989 dan PP Nomor 37 Tahun 1998, telah ditekankan beberapa perbuatan hukum yang menjadi tanggung jawab PPAT yaitu :

1) Mengenai kebenaran dari kejadian yang termuat dalam akta, misalnya mengenai jenis perbuatan hukum yang dimaksud oleh para pihak, mengenai sudah dilakukannya pembayaran dalam jual beli, dan lain sebagainya.

2) Mengenal baik data fisik maupun data yurudisnya

3) Mengenal identitas para penghadap yang merupakan pihak-pihak yang melakukan perbuatan hukum.

Dalam Peraturan Kepala Badan Pertanahan Nasional Nomor 6 Tahun 1989 dan PP nomor 37 Tahun 1998, telah ditekankan beberapa perbuatan hukum yang menjadi tanggung jawab PPAT, yaitu

1. Mengenai kebenaran dari kejadian yang termuat dalam akta, misalnya mengenai jenis perbuatan hukum yang dimaksud oleh para pihak, mengenai sudah dilakukanya pembayaran dalam jual beli, dan lain sebagainya.

2. Mengenai objek perbuatan hukum, baik data fisik maupun data yuridisnya;

3. Mengenai identitas para pengahadap yang merupakan pihak - pihak yang melakukan perbuatan hukum.

Apabila PPAT tidak mengetahui secara pribadi mengenai hal tersebut, PPAT dapat mencari kesaksian dari saksi - saksi yang disyaratkan dalam pembuatan akta. Kasus jual beli tanah yang berakhir pada sengketa sering mengemuka, baik di media cetak maupun elektronik dan mungkin yang tak terpublikasikan pun banyak. Karena itu, para calon pembeli tanah atau rumah sudah seharusnya mengetahui hal - hal apa saja yang seharusnya dipersiapkan agar tidak terjadi sengketa di kemudian hari. Ketika seseorang pembeli tanah, akan dihadapkan pada dua kemungkinan, pertama tanah yang akan dibeli memiliki sertifikat, dan yang kedua belum bersertifikat.

Sering kali dalam transaksi jual beli tanah timbil permasalahan. Dalam jangka pendek pembeli mungkin tidak akan mengalami gugatan dari pihak lain, tetapi dalam jangka panjang pembeli akan mengalami gugtan dari pihak lain yang merasa memiliki atau dirugikan akan hak atas tanahnya.

Banyak tanah yang belum bersertifikat atau tanah tersebut tidak mempunya bukti kepemilikan berupa sertifikat. Apabila tanah tersebut pernah didaftarkan untuk keperluan pemungutan pajak tanah (fiscal kadaster), maka biasanya bukti kepemilikan hak ats tanah tersebut berupa pipil, pethuk, leter C/D dan Bukti pajak 
lainnya. Bukti berupa pemungutan pajak atas tanah tersebut oleh sebagian masyarakat kita hingga saat ini masih dianggap sebagai bukti kepemiklikan ha katas tanah. Padahal secara yuridis surat-surat pemungutan pajak tersebut tidak membuktikan subjek dan objek suartu ha katas tanah.

Fakta lapangan yang terjadi terkait kurangnya kepedulian masyarakat umtuk memenuhi kewajiban mendaftarkan hak milik atas bidang tanahnya di Kantor Pertanahan menjadi cerminan tidak berjalannya hukum yang berlaku dengan yang diinginkan. Aturan yang berlaku hanya ditaati dan dijalankan oleh sebagian daripada masyarakat saja, hal ini merupakan fakta yang dijalankan oleh masyarakat yang tidak sejalan dengan kaidah hukum yang telah dibuat pemerintah yang kemudian disebut sebgai social lag ${ }^{3}$.

Syarat jual beli hak atas tanah baik yang bersertifikat maupun yang belum bersertifikat harus dibuktikan dengan akta otientik yang dibuat olehPPAT ditegaskan dalam pasal 37 ayat (1) Peraturan Pemerintah Tahun 1997. Dikalangan masyarakat Indonesia terutama tinggal dipedesaan hingga saat ini belum semuanya mengenal adanya PPAT. Dalam melakukan transaksi di bidang pertanahan masih ada sebagian masyarakat di pedesaan yang menuangkan dalam akta yang ditandatangani oleh para pihak dengan diketahui kepala Desa. Bahkan ada pula transaksi tanah yang hanya dituangkan dalam bentuk kwitansi pembayaran tanpa dibuatkan kata perjanjian. Model transaksi tanah yang seperti itu masih marak terjadi di kalangan masyarakat yang tinggal di Pedesaan, karena transaksi yang mereka buat dirasa cukup hanya dibuktikan dengan akta yang dibuat sendiri atau sekedar catatan adanya bukti pembayaran.

Keharusan adanya akta jual beli dibuat oleh PPAT tidak hanya pada hak atas tanah yang telah terdaftar (telah bersertifikat), namun juga pada hak ats tanah yang belum terdaftar (Belum bersertfikat) di Kantor Pertanahan Nasional. Apabila jual beli hak katas tanah yang belum terdaftar dilakukan dengan tujuan tidak untuk didaftarkan ke kantor pertanahan, maka proses jual belinya dapat dibuat dengan akta di bawah tangan (Bukan oleh PPAT). Dalam praktiknya, jual beli hak atas tanah ini dibuat dengan akta di bawah tangan oleh para pihak yang disaksikan oleh kepala Desa Lurah setempat di atas kerta bermaterai cukup. Dengan telah dibuatnya akta jual beli ini, maka pada saat itu telah terjadi pemindahan hak kepemilikan tanah dari pemegang hak sebagai penjual kepada pembeli sebagai pemegang hak yang baru.

3 Istiqamah, Tinjauan Hukum Legalisasi Aset Melalui Pendaftaran Tanah Sistematis Lengkap (Ptsl) Terhadap Kepemilikan Tanah. Jurnal Jurisprudentie: Jurusan Ilmu Hukum Fakultas Syariah dan Hukum Volume 5 Nomor 1 2018, h. 228.

94 
Perbuatan hukum berupa jual beli hak atas tanah yang belum terdaftar (belum bersertifikat) dan tujuan untuk didaftarkan ke kantor Pertanahan melalui pendaftaran tanah secara sporadic, maka jual belinya harus dibuat dengan akta PPAT. Sejak peraturan Pemerintah Nomor 24 Tahun 1997 berlaku efektif pada tanggal 8 oktober 1997, jual beli hak ats tanah yang belum terdaftar (belum bersertifikat) yang tidak dituangkan dalam akta otientik yang dibuat oleh PPAT, maka permohonan pendaftaran tanah akan ditolah oleh kantor Pertanahan. Agar permohonan pendaftaran tanah yang dilakukan secara sporadic dikabulkan oleh kantor pertanahan, maka harus dilakukan proses jual beli ulang oleh penjual dan pembeli dengan akta yang dibuat oleh PPAT. Apabila jual beli hak atas tanah yang belum bersertfikat dilakukan sebelum berlakunya PP Nomor 24 tahun 1997, maka bukti jual belinya cukup melalui akta dibawah tangan yang dibuat oleh kedua belah pihak dan dibenarkan dibenarkan dalam arti diketahui dan ditandatangani olerh kepla desa/Lurah. Sedangkan jika jual beli hak atas tanah yang belum bersertifikat tersebut dilakukan setelah berlakunya PP nomor 24 tahun 1997, maka pembuktian adanya jual beli hak atas tanah tersebut harus dibuat dengan akta PPAT, setelah itu barulah diajukan permohonanpendaftaran hak atas tanah tersebut ke Kantor Badan Pertanahan Nasional.

Keberadaan PPAT ditur dalam PP Nomor 24 Tahun 1997 Tentang pendaftaran tanah yang menegaskan bahwa PPAT adalah pejabat umum yang diberi kewenangan untuk membuat akta-akta tanah tertentu (Pasal 1 angka 24). Selanjutnya dalam PP Nomor 37 Tahun 1998 disebutkan bahwa PPAT adalah pejabat umum yang diberikan kewenangan membuat akta-akta otientik mengenai perbuatan hukum tertentu yang menyangkut hak atas tanah atau hak milik atas satuan rumah susun. PPAT diangkat dan diberhentikan oleh Menteri (sekarang Kepada BPN) untuk suatu wilayah kerja tertentu. Dalam rangka melayani kebutuhan masyarakat di daerah terpencil yang belum tersedia PPAT, menteri dapat menunjuk camat atau kepaa Desa sebagai PPAT Sementara; dan Kepla Kantor Pertanahan sebagai PPAT Khusus. Jabatan PPAT tidak boleh dirangkap dengan provesi advokat/pengacara, pegawai negeri sipil (termasuk hakim, jaksa) atau pegawai BUMN/BUMD.

Pembuatan sarana umum (jalan tol) untuk kepentingan umum, biasanya melibatkan banyak lokasi tanah masyarakat yang berstatus hak milik. Pembuatan sarana jalan tol tersebut sebelum dibangun harus melakukan tahapan pembebasan lahan sebagaimana yang termuat dalam UU No.2 tahun 2012 tentang pengadaan tanah bagi pembangunan untuk kepentingan umum. Terdapat ganti kerugian atas lokasi tanah yang akan terkena pelebaran dan pembuatan sarana jalan tol tersebut. Pembebasan tanah atau pengadaan tanah dilakukan dengan memberikan ganti 
kerugian terhadap nilai harga tanah yang akan dibebaskan, dengan menaksir harga tanah yang berada di dekat lokasi proyek pembuatan jalan tersebut. Penaksiran harga tanah yang terkena pembebasan lahan dilakukan tim penilai dari Kantor Badan Pertanahan dengan berkoordinasi kepada kepala desa/Lurah setempat yang masuk dalam lingkup wilayah kerja. Harga yang dibayarkan kepada masyarakat tidak jauh dari harga nilai tanah yang terletak di daerah tersebut.

\section{B. Pendaftaran Jual Beli Tanah yang Belum Bersertifikat}

Jual beli hak atas tanah yang belum bersertifikat harus mengikuti ketentuan sebagaimana diatur dalam pasal 37 Peraturan Pemerintah Nomor 24 Tahun 1997. Dokumen yang harus diserahkan kepada kantor Pertanahanan untuk keperluan pendaftaran hak adalah:

1) Permohonan pendaftrana tanah secara sporadik, dengan mengisi formulir (Model A) yang disediakan oleh Kantor Pertanahan.

2) Foto copy Kartu Tanda Penduduk pemohon dan/atau kuasanya yang masih berlaku.

3) Foto copy Kartu Susuna Keluarga (KSK/KK) dari pemohonan yang masih berlaku.

4) Bukti pelunasan Pajak Bumi dan Bangunan tahun terakhir.

5) Surat penguasaan penguasaan fisik bidang tanah yang ditandatangani oleh pemohon, dua orang saksi dan kepala Desa/Lurah.

6) Keterangan Kutipan Register Letter $C$ sebagai tanda pendaftran sementara tanh hak milik Indonesia, yang dibuat oleh Kepala Desa /Lurah.

7) Surat Keterangan Riwayat Tanah yang dibuat oleh Kepala Desa/Lurah.

8) Bukti perolehan tanah. Apabila tanah diperoleh melalui jual beli sebelum berlakunya PP Nomor 24 Tahun 1997 maka buktinya akata jual beli yang dibuat oleh para pihak dengan diketahui Kepala Desa/Lurah. Sedangkan jika hak atas tanah diperoleh melalui jual beli setelah berlakunya PP Nomor 4 Tahun 1997, maka buktinya harus tberupa akta jual beli yang dibuat oleh PPAT.

Setelah semua dokumen tersebut lengkap maka dilakukan tanpa prosedur pendaftran tanah secara sporadis sebagai berikut:

1) Mengajukan permohonan pendaftaran tanah secara sporadis kepada Kepala Kantor Pertanahan

2) Membayar biaya pendaftaran. Biaya pendaftaran ini telah ditetapkan dalam peraturan Pemerintah Nomor 46 Tahun 2002.

3) Setelah dilakukan pembayaran biaya pendaftaran, maka kemudian dilakukan pengukuran tanah oleh petugas ukur dari Kantor Pertanahan. 
4) Pengumpulan dan peraadilan penelitian data yuridis bidang tanah dan penetapan batas.

5) Pengumuman data fisik dan adata yuridis serta pengesahanya. Pengumuman dilakukan dalam waktu selama 60 hari, setelah jangka waktu pengumuman berakhir maka kemudian dilakukan pengesahan oleh Kepala Kantor Pertanahan.

6) Pembukuan hak, setelah dilakukan pengakuan dan pengesahan hak pasca diumumkan, maka kemudian dibuat buku tanah hak atas tanah tersebut yang ditandatangani oleh Kepala Kantor Pertanahan.

7) Penerbitan sertifikat, yang dilakukan setelah dibuatkan buku tanah hak atas bersangkutan, di mana kutipan data yuridis dan data fisik tanah yang tercantum dalam buku tanah jkemudian ditulis dalam sertifikat hak atas tanah tersebut.

8) Penyerahan sertifikat, yang dilakukan setelah sertifikat selesai dibuat dan ditandatangani oleh Kepala Kantor Pertanahan ${ }^{4}$.

\section{PENUTUP}

\section{A. Kesimpulan}

Berdasarkan pembahasan diatas maka, disimpulkan sebagai berikut :

1) Ganti kerugian atas pembebasan tanah dilakukan dengan memberikan ganti kerugian terhadap nilai harga tanah yang akan dibebaskan secara adil dan sesuai. Penaksiran harga tanah yang terkena pembebasan lahan dilakukan tim penilai dari Kantor Badan Pertanahan Nasional (BPN) dengan berkoordinasi kepada kepala desa/Lurah setempat yang masuk dalam lingkup wilayah kerja dengan melakukan musyawarah terhadap masyarakat yang memiliki tanah terkait dengan harga tanah yang akan diberikan. Harga yang dibayarkan kepada masyarakat tidak jauh dari harga nilai tanah yang terletak di daerah tersebut. Musyawarah yang dilakukan harus memperoleh kesepakatan mengenai harga yang tersebut agar dikemudian hari tidak terjadi konflik yang menuju ke pengadilan negeri.

2) Pembebasan tanah yang ditujukan untuk kepentingan umum selalu dibentuk panitia pengadaan tanah, dengan pembagian tugas masing-masing mulai dari bertugas mengukur, menggambar, lalu menghitung luas tanah serta status

4 (1) Undang-Undang Nomor 2 Tahun 2012 tentang Pengadaan Tanah Bagi Pembangunan untuk Kepentingan Umum (2) Peraturan Presiden Nomor 71 Tahun 2012 tentang Penyelenggaraan Pengadaan Tanah Bagi Pembangunan untuk Kepentingan Umum sebagaimana yang telah diubah beberapa kali, perubahan ketiga melalui Peraturan Presiden Nomor 30 Tahun 2015 tentang Perubahan Ketiga Atas Peraturan Presiden Nomor 71 Tahun 2012 tentang Penyelenggaraan Pengadaan Tanah Bagi Pembangunan Untuk Kepentingan Umum.

97 
hukum tanah tersebut. Kesepakatan letak batas yang diukur dikordinasikan kepada pihak Badan Pertanahan Nasional dan dibuktikan dengan tanda tangan pembeli dan pemilik tanah yang berbatasan dengan tanah yang akan dibuatkan pelebaran jalan. 


\section{DAFTAR PUSTAKA}

\section{Buku}

Adrian, Sutedi. Peralihan Hak Atas Tanah Dan Pendaftarannya. Jakarta: Sinar Grafika, 2017.

Damanik, Jayadi. Pembaruan Agraria dan Hak Asasi Petani. Yogyakarta: Lapera Pustaka Utama, 2012.

Gumelar, Agum. Kebijakan Agraria/Pertanahan Dari Perspektif Pertanahan Keamanan Dalam Konteks Negara Kesatuan Republik Indonesia. Bandung: Mandar Maju, 2001.

Hartanto, Andy J. Hukum Pertanahan Karakteristik Jual Beli Tanah yang Belum Terdaftar Hak Atas Tanahnya. Surabaya: Laksbang Justitia, 2014.

Hutagalung, Sukanti, Arie, dan Gunawan, Markus. Kewenangan Pemerintah di Bidang Pertanahan, Jakarta: Radjawali Press, 2008.

I.P.M. Ranuhandoko, Terninologi Hukum Inggris-Indonesia, Cetakan Kedua. Jakarta: Sinar Grafika, 2000.

Noor, Aslan. Konsep Hak Milik Atas Tanah Bagi Bangsa Indonesia. Bandung: Mandar Maju. 2018.

Sutedi Andrian. Peralihan Hak Atas Tanah dan Pendaftarannya. Jakarta: Sinar Grafika, 2013.

Sembiring Rosnidar. Hukum Pertanahan Adat. Depok: Rajawali Pers, 2017.

Santoso, Urip. Hukum Agraria dan Hak- Hak Atas Tanah. Jakarta: Kencana, 2009.

Urip Santoso. Hukum Agraria Kajian Komperhensif. Jakarta: Prenada Media, 2012.

Waskito, Arnowo Hadi. Pertanahan, Agraria, dan Tata Ruang. Jakarta: Prenada Group, 2017.

\section{Jurnal}

Istiqamah. Tinjauan Hukum Legalisasi Aset Melalui Pendaftaran Tanah Sistematis Lengkap (Ptsl) Terhadap Kepemilikan Tanah. Jurisprudentie: Jurusan Ilmu Hukum Fakultas Syariah dan Hukum, Volume 5 Nomor 1 2018.

Rahayu Subekti, Kebijakan Pemberian Ganti Kerugian Dalam Pengadaan Tanah Bagi Pembangunan Untuk Kepentingan Umum. Yustisia :Jurusan Ilmu hukum Fakultas Hukum Universitas Sebelas Maret, Volume 5 Nomor 2 Mei - Agustus 2016.

Agung Basuki Prasetyo, Prinsip Pengadaan Tanah Bagi Kepentingan Umum, Administrative Law \& Governance Journal, Volume 1 Edisi 3 Agustus 2018. 
Mukmin Zakie, Pengadaan Tanah Untuk Kepentingan Umum (Perbandingan Malaisia dan Indonesia. Ius Quia Iustum Universitas Islam Indonesia Volume 18Oktober 2011.

Hardianto Djanggi, Salle. Aspek Pengadaan Tanah Bagi Pelaksanaan Pembangunan Untuk Kepentingan Umum. Pandecta Jurnal Penelitian Ilmu Hukum Universitas Negeri Semarang (Research Law Journal), Volume 12 Nomor 22017.

Mohammad Mulyadi. Implementasi Kebijakan Pengadaan Tanah Untuk Kepentingan Umum di Jakarta Utara. Aspirasi: Jurnal MasalahMasalah Sosial. Pusat Penelitian Badan Keahlian DPR RI, Volume 8 Nomor 2017. 